\title{
Effects from Brexit on the EU-27 and the Euro Area Developments
}

\author{
Kaloyan Simeonov, Dr. Habil. ${ }^{1}$
}

Received: 25.06 .2021

Available online: 20.12 .2021

\begin{abstract}
Brexit affects all the aspects of life, business and European integration process. It has strong implications also on the developments in the Euro Area despite the fact that the United Kingdom had the so-called "opt-out clause" for not adopting the single currency within the EU as well as despite the abstinence of the UK from participation in the Banking Union of the EU. The purpose of this study is to analyse some important aspects of the influence of Brexit on the EU-27 and the Euro Area developments. It is too early to draw final conclusions on the effects of Brexit on the EU-27 and the Euro Area developments. However, some possible implications may be outlined even today as for example the opportunity for consolidation of the Euro Area and its current reforms, possible implications for the EU decision making process and even a possible stimulation of the enlargement of the Euro Area.
\end{abstract}

Keywords: Euro Area, Brexit, Economic and Monetary Union, Banking Union, Euro adoption JEL: E50, F30

\section{Introduction}

The withdrawal of the United Kingdom from the European Union affects every single aspect of the European integration process. Notwithstanding the fact that the United Kingdom had the so-called "opt-out clause" for Euro Area participation and that it did not take part in the Banking Union, Brexit has strong implications in relation to the development of the EU-27 and the Euro Area.

Before Brexit, there were 9 out of $28 \mathrm{EU}$ Member States that were outside the Euro Area. After Brexit this proportion is 8 out of $27 \mathrm{EU}$ Member States. However, as the United Kingdom was the second largest EU economy and the biggest one outside of the Euro

1 Associate professor, Head of the European Studies Department, Faculty of Philosophy, Sofia University "St. Kliment Ohridksi". E-mail: kdsimeonov@phls.uni-sofia.bg 
Area, the economic power and influence of the non-Euro Area Member States has dropped substantially after Brexit. Today the 8 non-Euro Area Member States comprise only about a small proportion of the EU economy.

The Brexit may affect the EU-27 and the Euro integration process in several ways. First, the reforms on the completion of the Economic and Monetary Union may be further streamlined as there will be no internal and tacit opposition from the United Kingdom. The EU decision making process may be also affected as it is difficult for the non-Euro Area Member States to reach a blocking minority in EU-27. Last but not least, Brexit may consolidate further the Euro Area and stimulate its enlargement process. The accession of Bulgaria and Croatia in the ERM II and the Banking Union in 2020 may be just the first step in that direction.

The purpose of this paper is to analyse some of the important aspects of the influence of Brexit on the EU-27 and the Euro Area developments. Given the volume of the analysis, at this stage it is not possible to make an exhaustive list of implications. However, some of the most important ones are taken on board and discussed. The research method is based mainly on the comparative analysis of some aspects that affect the EU-27 and the Euro Area before and after Brexit.

\section{The Euro Area before Brexit}

The United Kingdom was not part of the Euro Area before its withdrawal from the European Union. Furthermore, in the EU-28 there were only two EU Member States with the so-called "opt-out clause" for non-adopting the single currency even if they fulfill the Maastricht convergence criteria. These two EU Member States were United Kingdom and Denmark. After Brexit only Denmark has this "opt-out clause" in EU-27 in relation to the entry in the Euro Area. The "opt-out clause" has a very strong political meaning as it clearly demonstrates the choice of the country to abstain from deeper integration in the economic and monetary field. In fact, other Member States like Sweden, Poland, Hungary and Czech Republic do not have such "opt-out clause" but they are unwilling to make efforts or take steps towards adopting the single currency soon.

The United Kingdom was not part of the Banking Union either when it was still EU Member State. The Banking Unions consist of the Single Supervisory Mechanism where the European Central Bank has taken supervisory control over the significantly important banks; the Single Resolution Mechanism; the Single Rulebook as well as the European Deposit Insurance Scheme that is still under construction. The participation in the Banking Union is obligatory for the EU Member States that are part of the Euro Area. For the nonEuro Area Member States there is an optional opportunity to participate in the Banking Union through the so-called closed cooperation between the ECB and the respective national supervisory institution, usually the central bank (Simeonov, 2015).

Although the United Kingdom did not participate in the Banking Union and the Euro Area before its withdrawal from the European Union, their development was affected by 
the membership of the United Kingdom in the EU. For example, one of the preconditions for the start of the inauguration of the Banking Union after 2012 was its establishment mainly for the Euro Area countries, while non-Euro Area countries were only left an option to participate. It was clear from the beginning that the United Kingdom was reluctant to give up the control of its significant banks to the Frankfurt-based European Central Bank.

\section{Possible further stimulation and consolidation of Euro Area reforms}

After the global economic and financial crisis that started in 2007-2008 and affected also the EU, the Union initiated substantial reforms. The majority of these reforms aim to significantly modify the structure and the way that the Economic and Monetary Union functions and operates. Some of the reforms are targeted only at the Euro Area.

Brexit may further affect these changes, considering that more and more reforms will continue to be directed to the area of the single currency. It is quite likely that Brexit will consolidate further the Euro Area countries and the changes they initiate in that area.

Furthermore, after Brexit the Euro Area GDP comprises today about $85 \%$ of the total EU economy (GDP) and the 8 non-Euro Area countries comprise only about $15 \%$ of the EU economy. ${ }^{2}$ Before Brexit and the withdrawal of the second largest economy in EU-28, the 9 non-Euro Area countries counted for about one third of the EU economy. The difference between the economic influence in the EU of the non-Euro Area countries before and after Brexit is significant.

One of these reforms was the establishment of the already mentioned Banking Union. The fact that the United Kingdom was not willing to participate in the Banking Union was one of the main reasons to shape that union in a way where it was obligatory only for the Euro Area countries. A clear signal for the importance of the Banking Union is the fact that its participation is now obligatory also for countries that want to join the Exchange Rate Mechanism II (ERM II).

Participation in ERM II with a stable national currency is a precondition for entering in the Euro Area. However, so far there has been no legal requirement that accession in ERM II, the pre-Euro Area step, shall be coupled with Banking Union membership. This is rather a political commitment that was established by the Eurogroup during the preparation of Bulgaria and Croatia for ERM II accession (Eurogroup, 2018; Eurogroup, 2019). ${ }^{3}$ The Eurogroup statement explicitly mentions that a similar approach for simultaneous participation in the Banking Union and ERM II is expected to be applied to other EU Member States wishing to join ERM II so that the principle of equal treatment is adhered to.

2 Source: Author's calculations based on Eurostat data about GDP volumes in the EU.

3 A statement of Eurogroup is not a legal act as for example an EU Regulation and Directive. However, it has a strong political meaning, especially for the Bulgarian and Croatian efforts to join the ERM II and simultaneously the Banking Union. The legal requirements for joining the Single Supervisory Mechanism of the Banking Union with the so-called close cooperation mechanism before accession to the Euro Area are listed in Council Regulation (EU) No 1024/2013 of 15 October, 2013. This Regulation does not establish participation in the Banking Union as a precondition for joining ERM II. 
As already mentioned, Bulgaria and Croatia are participating in the Banking Union with the so-called close cooperation between the ECB and the national central banks. Therefore, currently the Banking Union comprises 21 out of 27 EU Member States.

Furthermore, the official authorities of Denmark and Sweden are also analysing possible participation in the Banking Union without joining ERM II (Denmark is already ERM II member) or the Euro Area. The enlargement of the Banking Union is a good example that Brexit may further consolidate the current EU reforms, although there is no a direct link between Brexit and Bulgaria and Croatia's accession to that union or the plans of Denmark and Sweden to join it.

Another area of reform after the global economic and financial crisis is the development of the Capital Markets Union (CMU). The CMU is designed for all the EU Member States and applies for the whole EU single market. The main goal for the CMU is to further develop the single market for capital in the EU. Currently financial markets in the EU-27 are mainly dominated by banking services. The idea of the CMU is not that investment services should compete with the banking services but rather that an additional channel of financing should be provided.

In contrast to the Banking Union, Brexit affects negatively the Capital Markets Union as the London city was the most developed capital market in EU-28. The Banking Union and the Capital Markets Union are important elements of the establishment of a Financial Union that shall target the effects from the global economic and financial crisis that broke out more than 10 years ago.

Another case in point showing that the United Kingdom abstained from following reforms in the EU that affect also the functioning of the EMU, is the signing of the socalled Fiscal Compact in March 2012. This is the Treaty on Stability, Coordination and Governance (TSCG) in the Economic and Monetary Union. Among the EU-27 at that time, only the United Kingdom and the Czech Republic did not sign this Intergovernmental Treaty that aimed to introduce stricter and more detailed rules to the Stability and Growth Pact. Some of the signatory Member States did not adhere to all its provisions. The withdrawal of the United Kingdom from the EU may facilitate the introduction of the provisions of this Intergovernmental Treaty into the EU legal framework. This is one of the goals of the current EU reforms in the area of the Economic and Monetary Union.

Other reforms in relation to the Euro Area may be also positively affected by the withdrawal of the United Kingdom from the European Union. The European Semester that aims to coordinate economic policies among EU Member States may be further streamlined. The idea to introduce the position of a European Minister of Finance (European Commission, 2017a) at least for the Euro Area may be reincorporated within the EU agenda.

The efforts to establish a Fiscal Union within the Euro area may be also streamlined. The macroeconomic imbalances procedures, other measures to complete the Economic Union may be also advanced without the opposition on the part of the United Kingdom.

Therefore, although Brexit has overall negative economic consequences for both the EU and the UK, the withdrawal of the United Kingdom from the EU may have at the same time 
a positive effect for the consolidation and further streamlining of the reforms in the Euro Area. These reforms aim to complete the Economic and Monetary Union by establishing solid Economic, Fiscal and Financial Union that will be further integrated with the Monetary Union. ${ }^{4}$ They may in turn lead to a stronger Political Union in the future.

\section{EU decision making process after Brexit}

The withdrawal of the United Kingdom from the EU will affect also the EU decision making process. The role of the non-Euro Area Member States will be further diminished in that process.

According to the Treaty on the Functioning of the EU (Article 238.3), as from 1 November 2014 and subject to the provisions laid down in the Protocol on transitional provisions, a qualified majority shall be defined as at least $55 \%$ of the members of the Council representing the participating Member States, comprising at least $65 \%$ of the population of these States. This double system applies for the majority of the decisions that are taken in the EU, given that the areas where unanimity by all Member States is required are few policy areas such as taxation and measures concerning social security or social protection.

The Treaty on the Functioning of the EU stipulates also that a blocking minority shall include at least the minimum number of Council members representing more than $35 \%$ of the population of the participating Member States, plus one member (Treaty on the Functioning of the European Union).

After Brexit, the EU-19 (the members of the Euro Area) represents $70.4 \%$ of the Member States and $76.5 \%$ of the total EU population. Therefore, the blocking minority which can block the adoption of a EU legal act by a double qualified majority, will be more difficult for the non-Euro Area Member States to achieve (Tokarski and Funk, 2019). The role of the non-Euro Area Member States decreases significantly after Brexit, taking into account that the population of the United Kingdom comprises more than 66 million people (Office for National Statistics of the UK).

Currently, there are no many cases in the EU decision making process where the countries are divided in their voting preference as Euro Area and non-Euro Area Member States. Furthermore, usually even in cases where qualified majority is required, Member States are trying to find a consensus on each legal act or decision and not to cut off a group of countries or even a single Member State. However, taking into account that there will be more decisions in the future that will affect directly or indirectly the reforms in the Euro Area, such kind of decisions that will possibly bring about a division between Euro Area and non-Euro Area Member States may become more frequent and important.

It should be also noted that the UK's "weight" in the EU decision making process was not only in terms of its population but was also due to the negotiation skills of its diplomats.

4 For more information in relation to the reforms for completing the Economic and Monetary Union see Juncker et al., 2015; European Commission, 2017/b). 
The UK diplomats are well trained and they properly defended the interests not only of the country but also of the group of the non-Euro Area Member States.

Another example of the importance of Brexit in $\mathrm{EU}$ decisions are the voting procedures within the European Banking Authority (EBA). When the Single Supervisory Mechanism within the Banking Union was approved, the EU regulators changed the voting rules in the Board of Supervisors in the EBA - the main decision-making body in that authority. Since then, in order for a decision to be adopted in the Board of Supervisors in EBA a simple majority of the members of the Banking Union is required as well as a simple majority of the countries not participating in the Banking Union (non-participating EU Member States). Each voting member has one vote. This system of double majority will no longer be in place once there are no more than four Member State outside the Banking Union and its Single Supervisory Mechanism. In such a case the decision by the EBA Board of Supervisors may be taken when at least one vote from non-participating Member State is attained (Regulation (EU) No 1093/2010). This system of double majority was introduced during the establishment of the Single Supervisory Mechanism in 2012-2014 with the significant influence of the United Kingdom.

Brexit decreased the number of non-participating Member States as well as the influence of non-participating Member States in the European Banking Authority. Furthermore, the European Banking Authority was based in London and after Brexit it was relocated to Paris. The accession of Bulgaria and Croatia to the Banking Union further reduced the number of non-participating Member States in the Single Supervisory Mechanism to only six Member States.

As a conclusion, it may be stated that the Brexit affected substantially the EU decision making process. The withdrawal of the United Kingdom from the EU decreased the influence of the non-Euro Area Member States in the Council of the EU as well as in the Board of Supervisors of the European Banking Authority.

\section{Brexit and Euro Area enlargement}

Although not directly, Brexit may affect also Euro Area enlargement process. This can be attributed not only to the decreasing influence of the non-Euro Area Member States in the EU decision making process but also to other factors. If the Euro as a single currency increases its influence in the global economic, trade, capital, foreign exchange and other markets and if the benefits from being part of the single currency area further increase, the attraction of that area for these eight countries will be also growing.

We should also bear in mind that the Euro is meant to be the currency for the whole European Union and the entire single market, not only for two/thirds of its Member States. This was the design of the single currency and the Economic and Monetary Union from its outset. However, from since the start of the functioning of the EMU there has always been a significant group of EU Member States that stay outside that area. 
The eight EU Member States that are not part of the Euro Area are a fairly heterogeneous economic group. As pointed out by some authors, they differ in terms of both economic development and economic competitiveness. For example, Denmark's gross domestic product per capita (if not measures by the Purchasing Power Parity standard) is seven times higher than that of Bulgaria (Tokarski and Funk, 2019). In general, Denmark and Sweden are much more developed than the Visegrad countries that are outside the Euro Area (Poland, Czech Republic and Hungary) and even more so than Croatia. The gap in economic development and national wealth is even higher when comparing Denmark and Sweden with Bulgaria and Romania.

As already stated, the economic influence of the non-Euro Area Member States is quite small after Brexit, taking into account that these eight countries represent only $15 \%$ of the EU-27 GDP. Although this figure does not have an official meaning in terms of EU decisions or policies, it has a significant political relevance. The United Kingdom was also the big and more reliable ally of these eight countries when the country was still part of the EU-28.

Therefore, it is expected that Brexit may further boost the Euro Area enlargement process and increase the appetite for accession among the non-Euro Area Member States and also increase involvement within the single currency area itself. A clear proof of that projection is the accession of Bulgaria and Croatia in 2020 to the Exchange Rate Mechanism II and the Banking Union of the EU. After July 2020 the ERM II encompassed three Member States - Bulgaria, Croatia as well as Denmark that has taken part in that mechanism since it was set up in January 1999.

The current Euro Area enlargement process started officially with Eurogroup Statement on the Bulgaria's path towards ERM II from July 2018 followed by the Eurogroup Statement on the Croatia's path towards ERM II from July 2019 (Eurogroup, 2018; Eurogroup, 2019). These Eurogroup statements lay down the main conditions that the two countries shall fulfill in order to be ready for ERM II entry. One of the main conditions that shall apply also for ERM II newcomers is that they shall join the EU Banking Union on their ERM II accession date at the latest. By virtue of this requirement the European Central Bank (ECB) gets directly involved in ERM II accession, given that the ECB shall make an asset quality review and a stress test of the significantly important banks in the acceding countries before deciding on a so-called close cooperation with the supervisory authorities (the central banks) of these two countries.

Other requirements for Bulgaria and Croatia on the road to ERM II accession were those in the areas of banking and non-banking supervision, national insolvency frameworks and quality of national statistics, measures against money laundering or terrorist financing, governance of state-owned enterprises, among other. This process further required that some amendments be made to the Bulgarian and Croatian legislation so that the two countries are prepared for ERM II and Banking Union accession. The majority of the preERM II requirements for Bulgaria and Croatia were quite similar. However, there were also some specificities taking into consideration the specific situation in both countries. 
Bulgaria and Croatia may not be alone in their efforts to join the Euro Area soon. It is likely that Romania will also start such a process. At this stage it is not very likely that Denmark and Sweden (the first one with the "opt-out clause") will initiate steps towards Euro Area accession. The same applies also for Poland, Hungary and Czech Republic. However, in the event that the Euro increases its role in Europe and on a global scale or that Bulgaria and Croatia and even Romania successfully join the Euro Area, such prospects may change.

These processes are influenced by the withdrawal of the United Kingdom from the European Union. Brexit may trigger steps towards uniting all or almost all the EU Member States within the single currency area.

\section{Conclusion}

The withdrawal of the United Kingdom from the European Union has a negative impact on the economic development of both the UK and the EU. Brexit has negative implications for the influence on the non-Euro Area countries in the EU-decision making process. Their influence decreases in the Council of the EU, the Board of Supervisors of the European Banking Authority as well as in other EU bodies and agencies.

However, the withdrawal of the United Kingdom from the European Union has also some positive impact. One of the positive effects of Brexit is the consolidation and possible streamlining of the reforms of the Euro Area. The United Kingdom did not mount strong opposition to the Euro Area reforms during its EU membership. However, some reforms such as the establishment of the Banking Union or the signing of the Fiscal Compact were influenced by the United Kingdom's abstention from participation.

After Brexit the Euro Area reforms may be further enhanced. They were initiated mainly as a result of the global economic and financial crisis that erupted in 2007-2008. These reforms currently aim to complete the Economic and Monetary Union through measures for establishing a genuine Economic, Fiscal and Financial Union.

The withdrawal of the United Kingdom from the EU may affect also the enlargement process of the Euro Area. A clear proof of that is the green light for Bulgaria and Croatia to join in 2020 the ERM II and the Banking Union. Romania may soon follow suit.

Even though countries like Denmark, Sweden, Poland, Czech Republic and Hungary are not expected to try to join the Euro Area in the near future, if the single currency increases further its influence on the European or global markets and if the accession of countries like Bulgaria and Croatia proves to be successful, other countries may also change their strategies towards accession to the Euro Area.

Brexit affected all the aspects of business and economic relationships in the European Union. It also affected the developments in the Euro Area. The future will show how deep are the effects of Brexit on the single currency. 


\section{References}

Capital Markets Union reforms in the EU. Website of the European Commission. Available at https://ec.europa.eu/info/business-economy-euro/growth-and-investment/ capital-markets-union_en (last visited May, 2021).

Consolidated version of the Treaty on the Functioning of the European Union, Official Journal C 326, 26/10/2012, p. $0001-0390$.

Council Regulation (EU) No 1024/2013 of 15 October, 2013 conferring specific tasks on the European Central Bank concerning policies relating to the prudential supervision of credit institutions. OJ L 287, 29.10.2013, p. 63-89.

Eurogroup. (2018). Eurogroup Statement on Bulgaria's path towards ERM II participation. Brussels, 12 July 2018.

Eurogroup. (2019). Eurogroup Statement on Croatia's path towards ERM II participation. Brussels. 8 July 2019.

European Commission. (2017/a). A European Minister of Economy and Finance. Communication from the Commission to the European Parliament, the European Council, the Council, and the European Central Bank. Brussels, 6 December 2017. $\operatorname{COM}(2017) 823$.

European Commission. (2017/b). Reflection Paper on the Deepening the Economic and Monetary Union. Brussels, 31 May 2017. COM(2017) 291.

Juncker, J-C. in close cooperation with D. Tusk, J. Dijsselbloem, M. Draghi and M. Schulz. (2015). The Five President's Report: Completing Europe's Economic and Monetary Union. Brussels, June 2015.

Office of the National Statistics of the United Kingdom. Available at https://www.ons.gov. uk/ (last visited May, 2021).

Regulation (EU) No 1093/2010 of the European Parliament and of the Council of 24 November 2010 establishing a European Supervisory Authority (European Banking Authority), amending Decision No 716/2009/EC and repealing Commission Decision 2009/78/EC (consolidated text).

Simeonov, K. (2015). Sazdavane na bankov sauz v ES. Sofia: Universitetsko izdatelstvo "Sv. Kliment Ohridki". [Creation of the EU Banking Union],

Tokarski, P. and Funk, S. (2019). Non-euro Countries in the EU after Brexit. Between Fear of Losing of Political Influence and Euro Accession. SWP Comment 2019/C 03, January 2019. 